\title{
Pollution Prevention:A New and Improved Approach to Environmental Protection
}

\author{
Linda Feinstein Kareff
}

Linda Feinstein Kareff is currently employed as an environmental protection specialist with the U.S. Environmental Protection Agency in New York. She graduated from The George Washington University in 1993 with a master of public administration degree, concentrating in policy analysis and evaluation, and received a bachelor of science degree in economics from Cornell University in 1990.

The modern environmental movement, now nearly a quarter century old, is in the midst of a critical transformation. Government, at both the federal and state level, is shifting its approach to environmental protection from that of reaction to prevention. Reduced risks to human health and lower compliance costs to industry measure the success of this emerging strategy.

The costs of maintaining the old "command and control" response to pollution are staggering. The Environmental Protection Agency (EPA) estimates it has imposed $\$ 1.4$ trillion in compliance costs since the agency's founding in 1970. ${ }^{1}$ Public agencies and businesses have spent approximately $\$ 120$ billion annually (2.1 percent of the 1990 GNP) on pollution treatment and control. ${ }^{2}$ By the year 2000 , the EPA estimates that compliance with current environmental laws will cost nearly $\$ 160$ million annually (2.8 percent of the GNP). ${ }^{3}$

Given this magnitude of private and public expenditure, the effectiveness of environmental pollution control has been limited. A comparison of toxic release data across all media (air, water, hazardous waste) shows that in 1988, 6.5 billion pounds were released while in 1992, the total was about 3 billion pounds. ${ }^{4}$ Despite this apparent progress, close examination of separate media shows a mixed record. Preventing pollution-instead of controlling pollution-would measurably improve the success of federal environmental policy by reducing the number of chemicals released into the environment as well as lowering the cost and regulatory burdens on businesses.

Corporate resistance, statutory mandates, and structural divisions within agencies all impede progress toward pollution prevention. Although the technology and expertise necessary for effective pollution prevention improves year by year, regulatory mandates tend to discourage large firms from being innovative and the cost of utilizing the latest prevention strategies often keeps smaller firms in an informational vacuum. Federal laws regarding air, water, and various forms of waste emphasize prescribed clean-up methods and tend to shift pollution from one medium to another. The bureaucracy, in turn, is charged with enforcing legislation rather than promoting planning and innovation. The effective shift from a clean-up to a preventive policy depends on the success of planning initiatives and industry response.

This article defines pollution prevention and discusses policies that can be federally enacted to encourage pollution prevention. New Jersey provides a case study to evaluate the policies which effectively overcome the barriers and encourage pollution prevention, since the state has one of the oldest and most progressive pollution prevention laws in the nation.

\section{What is Pollution Prevention?}

According to the Environmental Protection Agency (EPA), pollution prevention refers to the reduction or elimination of pollution sources before they are generated. Such source reduction is achieved by several different approaches. One extmple is substituting one material for another that generates less waste material: car manufacturers might substitute water-based paints for solvent-based paints. Manufacturing process modifications can also achieve pollution prevention. $3 \mathrm{M}$ installed a closed-loop decanter system to separate solvents from water. The system then distills and recaptures a significant portion of the solvents, thereby reducing emissions dramatically. Additionally, resource recovery reduces pollution sources by reusing manufacturing emissions in other processes. Volkswagen, for example, collects, reconditions, and reuses waste plastics as soundproofing material, thereby diminishing waste 
and decreasing the use of raw materials."

Pollution reduction through prevention rather than treatment is preferred for several reasons. First, pollution prevention can reduce exposure to toxic chemicals in the workplace. Second, pollution prevention is an environmentally safer approach because it does not rely upon assessment of constantly changing risk, (Risks that were unknown twenty years ago are readily apparent today.) Pollution prevention operates on the assumption that it is prudent to utilize the least amount of hazardous substances as is technically and economically feasible.

\section{Government, at both the federal and state level, is shifting its approach to environmental protection from that of reaction to prevention.}

Third, pollution prevention improves business competitiveness by reducing costs associated with raw material purchases, disposal, regulatory compliance, and liability.? Kenneth Derr, the chief executive officer of Chevron Corporation, has observed that "pollution prevention may be the best way to get out of [the] regulatory net and reduce operating costs." ${ }^{18} 1992$ study by the environmental group INFORM of twenty-seven plants that had implemented pollution prevention programs found that, for each source reduction project, a company had an average savings of $\$ 351,000$ and an average 1.6 million pounds of waste reduction. For instance, the Exxon Chemical Company added simple "floating roofs" to sixteen of its two hundred chemical storage tanks that contained the most volatile chemicals, reducing evaporative emissions by 90 percent and saving $\$ 200,000$ per year. ${ }^{9}$

A study by Stuart Hart, director of the corporate environmental management program at the University of Michigan-Ann Arbor, affirms pollution prevention's financial benefits. Hart conducted a statistical analysis to measure the effects of pollution reduction on financial performance from 1988 to 1991, using 127 companies from Standard \& Poor's 500-stock index. After controlling for variables such as research and development intensity and firm size, Hart found that pollution prevention increased a company's operating performance and financial returns. ${ }^{10}$

\section{Barriers to Pollution Prevention}

Despite the common sense appeal, many barriers exist to a shift from pollution control to pollution prevention. Present laws address environmental problems by requiring industry to clean up pollutants affecting particular media (air, water, or land). Government bureaucracies are organized to implement single-medium, command-and-control legislation. The water, air, and solid waste offices perform isolated regulatory functions that prevent a comprehensive remediation approach across all media.

Barriers also exist within industry. As a result, few companies have pursued pollution prevention programs outside of progressive states (e.g., New Jersey). Regulatory barriers (restrictive and inflexible environmental laws and regulations) often dictate certain pollution controls and dissuade businesses from seeking innovative pollution-prevention tactics. Businesses may also lack investment capital to pursue environmental protection beyond statutory compliance. Some company officials contend they already spend significant dollars on environmental concerns, thus deterring investment in voluntary pollution prevention. Although many companies lack access to affordable information about pollution prevention benefits, internal corporate attitudes resisting voluntary environmental change also constitute distinct barriers to pollution prevention.

\section{Pollution Prevention in New Jersey}

State-administered pollution prevention programs vary. The General Accounting Office (GAO) found that many state programs claiming to conduct pollution prevention actually involved the recycling, treatment, or disposal of waste." New Jersey is among the early leaders in encouraging industrial pollution prevention. New Jersey's 1991 Pollution Prevention Act, requiring industries to consider pollution prevention options, highlights the financial benefits, and thus encourages voluntary implementation.

The New Jersey program's three components-integrated permitting, regulatory integration, and facility-wide planning-encourage a comprehensive approach to pollution prevention. ${ }^{12}$ The first component, an integrated permitting pilot project, develops necessary procedures for preparing and issuing facility-wide permits. The state's fifteen-company test consolidates air, water, and hazardous waste permit requirements, and each company's pollution prevention plan, into a single permit. The program uses a permit team approach that includes staff from each media office and the pollution prevention office.

By issuing permits on a facility-wide basis (rather than for specific media within each plant) the New Jersey 
Department of Environmental Protection (DEP) takes a holistic approach to a facility. This will help the facility and DEP to develop a strategy that minimizes pollution in the most cost-effective manner, often through preventive approaches. Problems such as shifting pollution from the air to the water, and then to the ground, which often occurs with media-specific regulation, are eliminated. Businesses also enjoy the increased efficiency of a streamlined permitting process. Project results and recommendations for broader application must be reported to the state legislature in $1996 .{ }^{13}$ Firms involved in the pilot are lured by the prospect of diminished paperwork, special access to top-level DEP management, and a voice in shaping the program, according to DEP officials. ${ }^{14}$

\section{The New Jersey pollution prevention program overcomes several barriers to implementing pollution prevention with minimal regulation.}

The second program component, regulatory integration, eradicates regulatory and monetary disincentives and creates positive statutory and regulatory incentives for a company to pursue pollution prevention. In practice, however, regulatory integration connotes activities ranging from training state enforcement personnel to sending letters to industry stating a preference for pollution prevention. According to Jeanne Herb, Director of the New Jersey Office of Pollution Prevention, "regulatory integration is the hardest part of pollution prevention to crack." ${ }^{15}$ While other components, such as planning, are clear objectives, defining what it means to fully integrate pollution prevention into the regulatory structure is more difficult.

Prevention reporting, included in the facility-wide permitting program, represents an important step toward regulatory integration by the New Jersey DEP. By linking integration with permitting, New Jersey officials hope that prevention opportunities develop from industry initiative rather than DEP mandate. ${ }^{16}$ The department plans to incorporate recommendations regarding regulatory integration in its 1996 report to the state legislature.

Facility-wide planning, the third component, requires companies to develop process- level pollution prevention plans (changes regarding manufacturing operations) and submit plan summaries and annual progress reports to DEP. The facility thereby identifies opportunities, sets priorities, and evaluates projects based on waste contribution, portion of chemical usage, and health and environmental risks. ${ }^{17}$ Source reduction opportunities are emphasized, not mandated. The New Jersey DEP also issues guidance explaining the planning process. Each company's plan is evaluated for its comprehensiveness rather than to determine whether the company uses a prescribed prevention method. Mandated facility-wide planning encourages firms to determine pollution prevention's economic benefits and stimulates industry innovation.

Early DEP analysis suggests varied industry responses to the pollution prevention planning requirements. Several companies claimed that the planning would have occurred without government intervention; others expended minimal planning efforts. Nonetheless, many companies that engaged in facility-wide planning developed alternative processes which reduced pollutants and production costs. A large chemical company representative concluded that the planning process encouraged upper management to support a prevention effort previously recommended but not undertaken. ${ }^{18}$

The New Jersey DEP reviewed thirty of four hundred plans submitted. The firms that prepared these reports-representing businesses of all sizes-estimated that plan development required an average of seventeen employee days, including time spent by engineering, environmental, management, production, and research and development staff. ${ }^{19}$ By extrapolating a participating facility's worst-case cost estimates of plan preparation to the approximately eight hundred facilities covered by the law, the New Jersey DEP yielded a total cost estimate of $\$ 18$ million. This estimate includes DEP's annual $\$ 2$ million program administration costs. ${ }^{20}$

Preliminary facility estimates project annual savings of $\$ 133$ million. A recent cost- benefit analysis showed that for every dollar spent, facilities anticipate $\$ 7.40$ in savings. ${ }^{21}$ The estimate excluded the environmental and worker health benefits of pollution prevention..$^{22}$ This DEP analysis illustrates how the benefits of developing pollution prevention plans may outweigh costs. During on-site visits, DEP officials asked facility operators whether they found the "time spent on pollution prevention worthwhile." A substantial majority ( 80 percent) found pollution-prevention planning worthwhile and cited reasons such as cost savings, less regulatory compliance, and a shared mission between staff not traditionally working together. ${ }^{23}$

The New Jersey pollution prevention program overcomes several barriers to implementing pollution prevention with 
minimal regulation. Regulatory integration and facility-wide permitting reduce regulatory disincentives and create positive incentives for pollution prevention. This is achieved by pursuing a comprehensive facility approach and eliminating overlapping or conflicting regulatory requirements. Mandatory planning overcomes the corporate inertia within New Jersey firms that resists voluntary environmental improvements. State guidance surmounts technological and informational barriers by apprising companies of pollution prevention methodologies and their benefits.

\section{Encouraging Pollution Prevention at the National Level}

Federal policymakers must balance existing environmental laws and pollution prevention programs. This balance is achieved by eliminating pollution-prevention barriers without eliminating the protection that existing regulations' provide. Thus, implementing pollution prevention does not imply dismantling the current federal regulatory system.

\section{Many businesses cannot or will not overcome informational barriers or corporate resistance to pollution prevention witbout the encouragement of government.}

In 1990, Congress enacted the Pollution Prevention Act, making pollution prevention a national objective. ${ }^{24}$ The act establishes a four-part hierarchy of environmental management priorities:

1. Pollution should be prevented or reduced at the source whenever feasible;

2. Pollution that cannot be prevented should be recycled whenever feasible;

3. Pollution that cannot be prevented or recycled should be treated in an environmentally safe manner whenever feasible; and

4. Disposal or release into the environment should be employed only as a last resort and should be conducted in an environmentally safe manner. ${ }^{25}$

Congress has also supported pollution prevention in single-media legislation. For example, the Clean Air Act Amendments of 1990 encourage pollution prevention in the utility industry by developing and limiting total amounts of sulfur dioxide releases in the environment without prescribing a method to limit such emissions.

In February 1991, the EPA declared pollution prevention the preferred agency strategy in confronting environmental problems. ${ }^{26}$ In keeping with this strategy, the agency developed several programs to encourage pollution prevention, including voluntary initiatives such as the 33/50 Program and "Green Lights." The 33/50 Program encourages participating companies to reduce Toxic Release Inventory (TRI) emissions by 33 percent in 1992 and 50 percent by 1995 , and allows companies to select how to achieve and account for these reductions. "Green Lights" seeks privatesector energy reduction commitments through efficient lighting installation. Although voluntary initiatives are a beginning, they are limited in terms of the number of facilities that participate and the number of toxic substances that are addressed. Additionally, the extent to which reductions result from pollution prevention rather than from pollution control is often unclear. ${ }^{27}$

Despite worthy goals in the declaration of a national environmental management hierarchy and an EPA pollution prevention strategy, only limited support for pollution prevention exists because these measures do not ensure the involvement of a large number of companies. As Stephen M. Johnson argues in "From Reaction to Proaction," the Pollution Prevention Act, much like EPA's pollution prevention strategy,

is largely symbolic, and its real power will be to create a legislative framework upon which future pollution prevention efforts can be built. The legislative history of the Act describes it as a "first step" towards accomplishing the pollution prevention objectives of the Act, and notes that "additional steps may be necessary to undertake a comprehensive pollution prevention program." ${ }^{28}$

Only additional legislative action can foster a transformation from environmental clean-up to a national pollution prevention policy.

In the 103rd Congress, Senator Joseph Lieberman (D-New Jersey) introduced the Hazardous Pollution Prevention Act (S. 980) to include pollution prevention planning in the TRI. The bill was developed after consultation with industry, state government, and environmental representatives. ${ }^{29}$ The proposal maintained the voluntary nature of pollution prevention by allowing EPA to evaluate the plans only for completeness and not substance..$^{30}$ The Integrated Pollution Prevention and Control Section of the Clean Water Act also 
facilitated federal pollution prevention policy by establishing a ten-facility pilot program to test whether integrated permits lower compliance costs, achieve greater environmental benefits, and encourage national source reduction. ${ }^{31}$

Support for the pollution prevention planning bill existed. among environmentalists and industry representatives. According to Morton Mullins of the Chemical Manufacturers Association, "Planning is an essential, if not the essential, milestone element of the pollution prevention process. We are totally supportive of it. We could not do the things we are doing without planning. ${ }^{132}$ Ultimately, the Hazardous Pollution Prevention Planning Act became a part of the Clean Water Act reauthorization which was never enacted.

\section{Pollution-prevention programs deserve the support of elected officials because these programs offer a rare "win-win" outcome: both businesses and the environment benefit.}

Many businesses cannot or will not overcome informational barriers or corporate resistance to pollution prevention without the encouragement of government. Yet, even with such encouragement, industry support for pollution-prevention is not likely to flourish until many regulatory constraints are removed. Clean Air and Clean Water Act requirements, for example, frequently constrain states and localities in performing inspections or writing media- specific permits based on an EPA method.

The EPA's Common Sense Initiative, comparable to New Jersey's regulatory integration effort, is an important step in the process. The Initiative undertakes a comprehensive evaluation of multi-media approaches to emissions reduction for six large inclustries. The goal of the effort is to replace a pollutant-by-pollutant approach with an industry-

\section{Notes}

tI would like to thank Jennifer Hicks for her helpful suggestions and hard work on the article, and Lauren Giniger for her diligent research. I would also like to thank Scott Kareff for his constant support.

The views expressed in this article are of the author and do not represent the policy or position of the U.S. Environmental Protection Agency. by-industry approach to improve environmental protection while decreasing associated costs. By involving agency representatives from each media office, industry groups, and environmental groups, the EPA hopes to achieve a more logical approach to each industry. The group will examine improvement opportunities in current regulation, pollution prevention, reporting, compliance, permitting, and environmental technology. ${ }^{33}$ Consensus within this diverse group may improve regulatory integration within each industry, enabling companies to achieve pollution prevention and, ultimately, avoid shifting pollution from one media to another (e.g., water to ground).

Mandatory pollution prevention planning, a key aspect of New Jersey's program, is still absent at the national level. Though the TRI requires public reporting of the manufacture, processing, or use of several hundred chemicals above certain thresholds, and contains forms for industry source reduction reporting, the TRI does not require industry to conduct pollution prevention planning. The EPA's plan to expand the TRI database includes suggested pollution prevention planning guidelines. Analysis by the EPA has shown that implementing these provisions could save industry between $\$ 500$ million and $\$ 2$ billion annually. ${ }^{3.4}$

\section{Conclusion}

The initial analysis by New Jersey's DEP indicates that the benefits of pollution prevention planning outweigh the costs, thus making New Jersey's approach a compelling example of innovative environmental protection. At the federal level, legislation mandating pollution prevention planning and cross-media approaches to environmental protection has not yet emerged in the 104th Congress. Nevertheless, pollution-prevention programs deserve the support of elected officials because these programs offer a rare "win-win" outcome: both businesses and the environment benefit. ${ }^{35}$ Only by learning about these advantages can Congress and industry begin to implement preventive environmental protection, *
${ }^{1}$ Peter Brimelow and Leslie Spencer, "You Can Get There From Here," Forbes (6 July 1992): 59; Thomas Mounteer, "The Inherent Worthiness of the Struggle: The Emergence of Mandatory Pollution Prevention Planning as an Environmental Regulatory Ethic," The Columbia.Journal of Environmental Law 19, No. 2 (1994): 261-262.

2Ibid.; Emily T. Smith, "Doing It for Mother Earth," Business Week ("Quality" special edition) (1991), 44. 
${ }^{3}$ General Accounting Office, Environmental Protection: Meeting Public Expectations with Limited Resources (Washington, D.C.: General Accounting Office, 18 June 1991), 8.

${ }^{4}$ Mounteer, 258; Environmental Protection Agency, 1992 Toxics Release Inventory: Public Data Release (Washington, D.C.: Environmental Protection Agency, 1992), 3.

sU.S. Environmental Protection Agency, Office of Policy, Planning and Evaluation and Office of Solid Waste, Pollution Prevention

Benefits Manual, (Washington, D.C.: Government Printing Office, 1989), 1. There has been significant debate as to what constitutes pollution prevention. Some argue that recycling should be included in the definition because recycling decreases pollution.

However, the true pollution prevention ethic is aimed at eliminating the creation of the pollutant in the first place. Therefore, policies that encourage recycling of wastes, while better than treating or disposing of the waste, circumvent the true goal of source reduction.

${ }^{6}$ Stephan Schmidheiny, Changing Course: A Global Perspective on Development and the Environment, (Cambridge: The MIT Press, 1992), 103-105.

'New Jersey Department of Environmental Protection, Office of Pollution Prevention, Ten Most Commonly Asked Question About: The New Jersey Pollution Prevention Act and Regulations, (Trenton, NJ: 1995), 2.

"Quoted in "Planning for Pollution Prevention," The Environmental Forum, Volume 10, Number 1, January/February $1993,24$.

'Joanna Underwood, "Going Green For Profit," EPA Journal 19, No. 3, (July-September 1993), 11.

${ }^{10}$ Otis Port, "Maybe It is Easy Being Green," Business Week, February 13, 1995, 80.

${ }^{1}$ U.S. General Accounting Office, Pollution Prevention: EPA Should Reexamine Objectives and Sustainability of State Programs, (Washington, D.C.: Government Printing Office, 1994), 3.

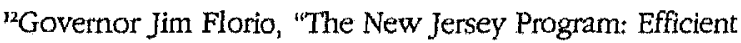
Businesses are seen as Key," EPA Journal 19, No. 3, (July-September 1993), 32.

${ }^{13}$ Ibid.

14 John Fried, Pbiladelpbia Inquirer, 27 February 1995.

${ }^{15} J$ eanne Herb, telephone conversation with author, 21 March 1995.
${ }^{16}$ Ibid.

${ }^{17}$ David Teeter, "Incorporating Pollution Prevention into Facility Permits," in Pollution Prevention: A Practical Guide for State and Local Government (Boca Raton: Lewis Publishers, 1993), 63.

${ }^{18}$ Deborah Milecovsky, telephone conversation with author, 16 February 1995.

${ }^{19} \mathrm{New}$ Jersey Department of Environmental Protection, Office of Pollution Prevention, DRAFT: Early Findings of the Pollution Prevention Program (Trenton, New Jersey: 1995), 2.

20Ibid, 3 .

"Ibid.

${ }^{22}$ Ibid.

${ }^{21}$ Ibid.

${ }^{24}$ U.S. Statutes at Large 104 (1990): 1388-327.

${ }^{25}$ Ibid.

${ }^{26}$ U.S. Environmental Protection Agency, Reducing Risk: Setting Priorities and Strategies for Environmental Protection, (Washington, D.C.: Government Printing Office, 1990).

${ }^{27}$ Senator Joseph Lieberman, "Pollution Prevention Planning," 27.

${ }^{28}$ Stephen M. Johnson, "From Reaction to Proaction: The 1990 Pollution Prevention Act," Columbia Journal of Environmental Law 17, no. 1 (1992), 170.

"Senator Joseph Lieberman, "Planning for Pollution Prevention," 27.

${ }^{30}$ Hazardous Pollution Prevention and Control Act of 1993, 103rd Cong., 1st sess., S. 980, Congressional Record, 139, no. 70, daily ed. (18 May 1993): $\$ 6042$.

31S. 1114, 103rd Cong., 1st sess.

${ }^{32}$ Quoted in "Planning for Pollution Prevention," 26.

${ }^{33}$ Carol Browner, Common Sense Initiative: A New Generation of Environmental Protection, (Washington, D.C.: Environmental Protection Agency, August, 1994).

${ }^{34}$ Senator Lieberman, "Planning for Pollution Prevention," 25.

${ }^{35}$ Environmental Protection Agency, issued by National Advisory Concil for Environment and Technology, Building State and Local Pollution Prevention Programs, (Washington, D.C.: Government Printing Office, 1992), 1. 


\section{Bibliography}

Brimelow, Peter, and Leslie Spencer. "You Can Get There From Here," Forbes (6 July 1992), 59-60.

Browner, Carol M. Common Sense Initiative: A New Generation of Environmental Protection. U.S. Environmental Protection Agency. Washington, D.C.: Government Printing Office, 1994.

Florio, Governor Jim. "The New Jersey Program: Efficient Businesses Are Seen as Key," EPA Journal 19 (1993): 31-33.

Hirschhorn, Joel S., and Kristen U. Oldenburg. Prosperity Without Pollution: The Prevention Strategy for Industry and Consumers. New York: Van Nostrand Reinhold, 1991.

Johnson, Stephen M. "From Reaction to Proaction: The 1990 Pollution Prevention Act," Columbia Joumal of Environmental Law 17, no. 1 (1992), 153-204.

Kiesche, Elizabeth. "Implementation: Big Issues for Small Firms." Chemical Week, 11 December 1991, 37.

Lieberman, Joseph I. "Planning for Pollution Prevention." The Environmental Forum 10, (1993): 22-27.

Mounteer, Thomas. The Inberent Worthiness of the Struggle: The Emergence of Mandatory Pollution Prevention Planning as an Environmental Regulatory Etbic, 19 Columbia Journal of Environmental Law 251, 258-262 (1994).

New Jersey Department of Environmental. Protection. Office of Pollution Prevention. DRAFT: Early Findings of the Pollution Prevention Program. 1995.

New Jersey Department of Environmental Protection. Office of Pollution Prevention. Ten Most Commonly Asked Questions About: The New Jersey Pollution Prevention Act and Regulations. 1995.

Pbiladelpbia Inquirer, 27 February 1995.

Port, Otis. "Maybe It Is Easy Being Green." Business Week, 13 February 1995, 80.

Schmidheiny, Stephan. Changing Course: A Global Perspective on Development and the Environment. Cambridge, Mass.: MIT Press, 1992.
Smith, Emily T., "Doing It for Mother Earth," Business Week ("Quality" special edition) (1991), 44.

Teeter, David. "Pollution Prevention: A Practical Guide for State and Local Government." In Incorporating Pollution Prevention into Facility Permits. Boca Raton: Lewis Publishers, 1993.

Underwood, Joanna. "Going Green for Profit: Industry has Barely Tapped lts Potential," EPA Journal 19 (1993): 9-13.

U.S. Environmental Protection Agency. see Browner, Carol M.

Building State and Local Pollution Prevention Programs. A report by the National Advisory Council for Environmental Policy and Technology. Washington, D.C.: Government Printing Office, December 1992.

Office of Policy, Planning, and Evaluation and the Office of Solid Waste. Pollution Prevention Benefits Manual. Washington, D.C.: Government Printing Office, October 1989.

Office of Solid Waste. Compendium of Pollution Prevention Barriers and Incentives. Washington, D.C.: Government Printing Office, April 1992.

Reducing Risk: Setting Priorities and Strategies for Environmental Protection. Washington, D.C.: Government Printing Office, September 1990.

1992 Toxics Release Inventory: Public Data Release. Washington, D.C.: Government Printing Office, 1994.

U.S. General Accounting Office, Environmental Protection: Meeting Public Expectations with Limited Resources. GAO/RCED-91-97 Washington, D.C., 18 June 1991.

Pollution Prevention: E.P.A. Should Reexamine Objectives and Sustainability of State Programs. GAO/PEMD94-8 Washington, D.C., January 1994.

U.S. Office of Technology Assessment. Serious Reduction in Hazardous Waste: For Pollution Prevention and Industrial Efficiency. Washington, D.C.: Government Printing Office, 1986. 